\title{
ROR1 wt Allele
}

National Cancer Institute

\section{Source}

National Cancer Institute. ROR1 wt Allele. NCI Thesaurus. Code C52205.

Human ROR1 wild-type allele is located within 1p32-p31 and is approximately 405kb in length. This allele, which encodes tyrosine-protein kinase transmembrane receptor ROR1 protein, is thought to be involved in skeletal and cardiac development, but an exact function has yet to be determined. 